\title{
P450 の遺伝子多型と薬物動態
}

\author{
千葉寛 \\ Polymorphism of Cytochrome P450 Genes and Drug Disposition
}

\author{
Kan CHIBA \\ Laboratory of Pharmacology and Toxicology, Department of Pharmacogenomics, \\ Graduate School of Pharmaceutical Sciences, Chiba University, Chiba
}

\begin{abstract}
Summary: Molecular genetics of cytochrome P450 enzymes (CYPs) in relation to the drug development and drug treatment are reviewed. CYPs play a key role in the metabolism of various drugs. The capacity of CYPs varies from one person to another, leading to variable rates of drug metabolism. This variability is mainly due to the genetic polymorphism of CYPs. A number of different functional alleles of different CYPs have been identified. CYP2D6, CYP2C19 and CYP2C9 are the three most well studied and best characterized. On the other hand, CYP3A4 is the most important isoform of CYPs which metabolizes more than half of substrate drugs of CYPs. Although CYP3A4 is known to show wide inter-individual variation, it has not been attributed to genetic factor but to rather induction and inhibition of this enzyme. However, up to now the existence of 12 mutant alleles have been reported for this enzyme and variable capacity of CYP3A4 is now recognized to be explainable in part by the genetic factors. In this article, CYP2D6, CYP2C19, CYP2C9 and CYP3A4 will be dealt with in some detail but other CYPs will be covered in outline.
\end{abstract}

Key words: Polymorphism, Cytochrome P450, CYP, CYP2D6, CYP2C19, CYP2C9, CYP3A4, CYP1A2, CYP2E1, CYP2A6, CYP2B6

\section{はじめに}

Cytochrome P450 (CYP)には多数の分子種があり, 外来性化学物質の代謝にかかわるヒトの分子種だけでも 20 種類近くが知られている．これらのうち，医薬品の 代謝にかかわる最も重要な分子種は CYP3A4 であり, CYP で代謝される医薬品の半数以上がこの分子種によ り主に代謝を受ける。CYP3A4 に続く分子種は CYP2D6 であり, CYP で代謝される医薬品の 4 分の 1 位がこの分子種により主に代謝を受ける。CYP3A4, CYP2D6 以外では, CYP2C9, CYP2C19, CYP1A2, CYP2E1 が重要であり, これら 6 分子種で CYPにより 代謝される医薬品の $95 \%$ 以上が説明されると考えられ ている. その他, 関係する医薬品の数はそれ程多くない が, CYP2A6, CYP2B6 も幾つかの医薬品の代謝に主要 な酵素としてかかわっている.

本稿ではこれらの CYP 分子種の遺伝子多型について, Human Cytochrome P450 Allele のホームページの記載 に基づき1), 医薬品開発あるいは臨床的な観点から薬物 動態との関係を概説する.

\section{CYP2D6}

CYP2D6 は $\beta$ 遮断薬 (メトプロロール, 他), 抗不整 脈薬 (フレカイニド, 他), 抗うつ薬 (イミプラミン, 他), 抗精神病薬 (ハロペリドール, 他)など 70 種類以 上の医薬品の代謝にかかわっている分子種である. CYP2D6 の活性が遺伝的に欠損している個体がいるこ とは, 20 年以上前から知られており, poor metabolizer (PM) とよばれていた. PMの頻度は白人種で7\%, 日 本人では 0.7\%であり, CYP2D6 で主に代謝される薬物 を PM が服用すると, 高い血漿中濃度が長時間続くた め副作用が起こりやすいことが知られている2).

$\mathrm{PM}$ の原因となる遺伝子変異は現在までに 16 種類報 告されているが, 白人種ではエキソン 4 の一塩基变異 に伴うスプライシング異常 $\left(C Y P 2 D 6^{*} 4\right)$, エキソン 5 の 1 塩基欠失に伴うフレームシフト $\left(C Y P 2 D 6^{*} 3\right)$, $C Y P 2 D 6$ 遺伝子全体の欠失 $\left(C Y P 2 D 6^{*} 5\right)$ が主要な変異 であり (Fig. 1), これらの変異遺伝子により白人種の $\mathrm{PM}$ の 90\%以上が説明可能とされている ${ }^{3)}$. 一方, モン ゴル人種やニグロ人種における $C Y P 2 D 6^{*} 4$ の頻度は白

千葉大学薬学研究院 遺伝子薬物学講座薬物学研究室 $\overline{7} 263-8522$ 千葉県千葉市稲毛区弥生町 1-33 
人種と比較すると極めて低く，このことがモンゴル人種 やニグロ人種では PM 頻度が低い原因と推定されてい る. 日本人の PM の原因遺伝子としては $C Y P 2 D 6^{*} 5$ が 最も多く(遺伝子頻度 : $4.1 \%)$, 以下 $C Y P 2 D 6^{*} 4(0.8$ \%), CYP2D6*14(0.7\%)，CYP2D6*18(0.5\%)が続い ている ${ }^{4-7)}$ (Fig. 2).

CYP2D6 の遺伝子变異は PM にとどをらず，中間型 の intermediate metabolizer の原因となる变異遺伝子 (CYP2D6*10)の存在も明らかにされている.これは, 188 番目のシトシンがチミンに置換した結果， 34 番目 のプロリンがセリンがに変わったもので，CYP2D6 蛋 白の安定性が低下し, 定常状態における発現量が低下す るためと考えられている ${ }^{8)}$.CYP $2 D 6^{*} 10$ の頻度は白人 種では数\%であるのに対し日本人では $39 \%$ と高い6,7).
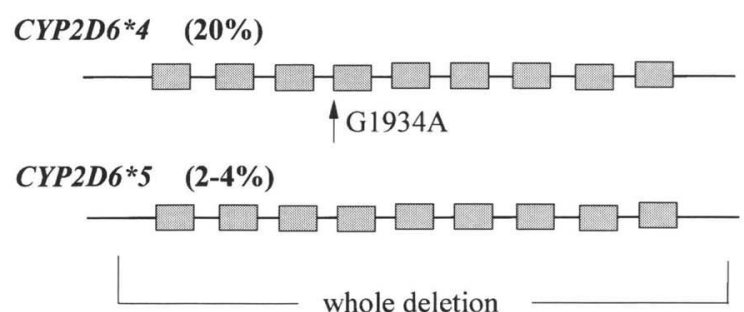

CYP2D6*3 $^{*}(1-2 \%)$

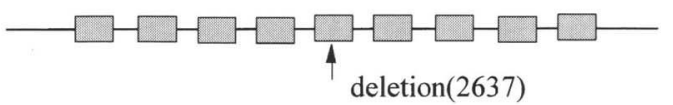

Fig. 1 Defective alleles of CYP2D6 frequently seen in Caucasians

Numbers in parenthesis are allele frequencies expressed as percentage in Caucasian population. Arrows indicate causative mutations for CYP2D6 deficiency.

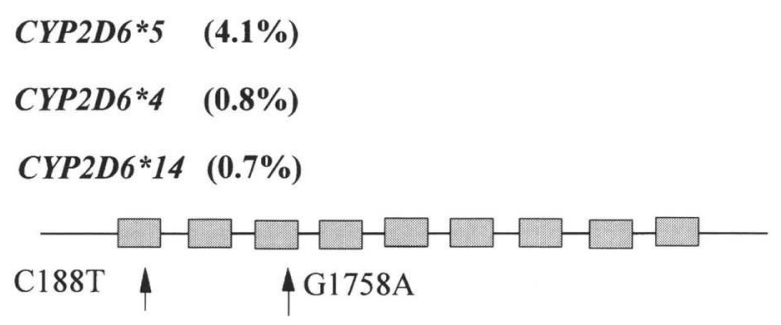

\section{CYP2D6*18 $(0.5 \%)$}

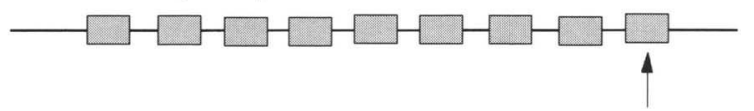

Insertion (TGCACCCGTG, 4213-4221)

Fig. 2 Defective alleles of CYP2D6 frequently seen in Japanese.

Numbers in parenthesis are allele frequencies expressed as percentage in Japanese population. Arrows indicate causative mutations for CYP2D6 deficiency.
一方，代謝能が通常のよりも大きい ultrarapid metabolizerの原因となる遺伝子増幅の存在も明らかにされて いる. 現在, 最大で CYP $2 D 6$ 遺伝子が 12 個増幅して いる例が報告されているが9)，これだけ増幅している例 はまれで， 2 個へ増幅した CYP2D6 のコーカサス人種 ${ }^{3}$ および日本人における遺伝子頻度は数\%である7).

\section{CYP2C19}

CYP2C19 で代謝される医薬品の数はそれ程多くはな いが，現在使用されているプロトンポンプ阻害薬は総て この分子種により代謝を受ける10). CYP2C19 の活性が 欠損している個体は CYP2D6 の場合と同様に PM とよ ばれており，日本人の $20 \%$ が CYP2C19 の PM であ る ${ }^{11)}$. 白人種の PM 頻度は約 $3 \%$ と低い11)。PM がオメ プラゾールを服用した場合，CYP2C19 の正常遺伝子を ホモで持つ個体と比較して血漿中濃度が 10 数倍高くな る.そのため, オメプラゾールとアンピシリンの併用に よるピロリ菌の除菌の成功率は PM でほぼ 100\%であ るのに対し，CYP2C19 の正常遺厷子をホモで持つ個体 では約 30\%に過ぎない12).

CYP2C19 の変異遺伝子が初めて報告されたのは 1994 年のことで, エキソン 5 の一塩基利一塩基置換に より mRNAの読み枠に未熟停止コドンが生じ機能を持 たない蛋白が作り出されることが明らかにされた13) (Fig. 3). この遺伝子变異 $\left(C Y P 2 C 19^{*} 2\right)$ により日本人 の PM の $70 \%$ ，コーカサス人の PM の 58\%が説明され る.続いてエキソン 4 にも未熟停止コドンを生じる 1 塩基置換 $\left(C Y P 2 C 19^{*} 3\right)$ が見出され，この変異と CYP2C19*2 を合わせると日本人の PM はほぼ $100 \%$ 説 明されるようになった ${ }^{14)}$. しかし，コーカサス人種に ついてはこの二つの遺伝子変異で PM の 87\%しか説明 されないが, 現在では上記以外に PM の原因となる 5 個の変異遺伝子の存在が明らかにされている11.

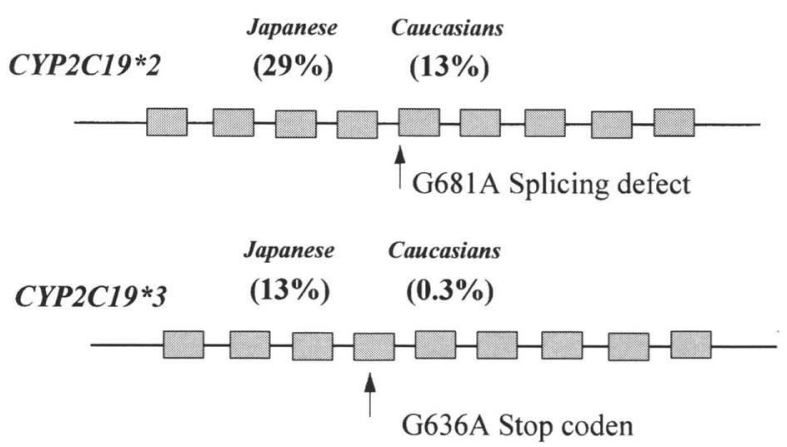

Fig. 3 Defective alleles of CYP2C19 frequently seen in Japanese and Caucasians.

Numbers in parenthesis are allele frequencies expressed as percentage. Arrows indicate causative mutations for CYP2C19 deficiency. 


\section{CYP2C9}

CYP2C9 は一連の非ステロイド性抗炎症薬，フェニ トイン，ワルファリン，トルブタミドなどの代謝にかか わっている分子種である15). CYP2C9 の活性を低下さ せる, あるいは低下させると推定されている变異遺伝子 は現在 4 つ $\left(\right.$ CYP $\left.2 C{ }^{*} 2,{ }^{*} 3,{ }^{*} 4,{ }^{*} 5\right)$ 報告さ机て抢り，ま だ論文として発表されていないものも7つある1 $\left(C Y P 2 C 9^{*} 6 \sim * 12\right)$. これらのうち, 臨床的に最も重要 なものは $C Y P 2 C 9^{*} 3$ であり，エキソン 7 の 1 塩基置換 により 359 番目のイソロイシンからロイシンへのアミ ノ酸置換が起こる．この変異タンパクは種々の基質に対 する活性が著しく低下していることが COS 細胞あるい は酵母を用いた発現系により明らかにされている。しか し，その低下の程度には基質により差があり，ピロキシ カム, テノキシカム, フェニトイン, メフェナム酸, ト ルブタミド，ワルファリンの水酸化活性は著しく低下す るのに対し, ジクロフェナクの 4 位水酸化活性の低下 は比較的少ない16) (Fig. 4)。このような基質による活性 低下の差異が in vivoでも認められるか否かは明確では
ないが，CYP2C9*3 をホモあるいはへテロで持つ個体 では, ワルファリン，トルブタミド，フェニトインのク リアランスが著しい低下を示すのに対し15)，ジクロフ エナクの 4 位水酸化活性は明確な低下を示さないことが 報告されている17)。

$C Y P 2 C 9^{*} 3$ の頻度は人種間で異なって扔り, コーカ サス人種では 6 ～ $8 \%$ であるのに対し日本人に抢ける頻 度は約 $2 \%$ であ ${ }^{18)}$ 。この頻度に基づくコーカサス人種 のホモ接合体の推定出現頻度は $150 \sim 300$ 人に 1 人であ るのに対し, 日本人の木モ接合体の推定出現頻度は 2500 人に 1 人と極示少ない.しかし，へテロ接合体 の推定出現頻度は約 25 人に 1 人であり, フェニトイン のように治療域が狭い薬物では十分に臨床的な問題とな りうる.

一方, $C Y P 2 C 9^{*} 2$ はエキソン 3 の 1 塩基置換であり 144 番目のアルギニンのシステインへの置換を伴う.こ のアミノ酸置換による CYP2C9 の活性の変化について は必ずしも一定の結果が得られていない，実際，この変 異を持つ個体から得られたヒト肝ミクロソームで CYP2C9 の活性がほとんど変化していないのに対し19),
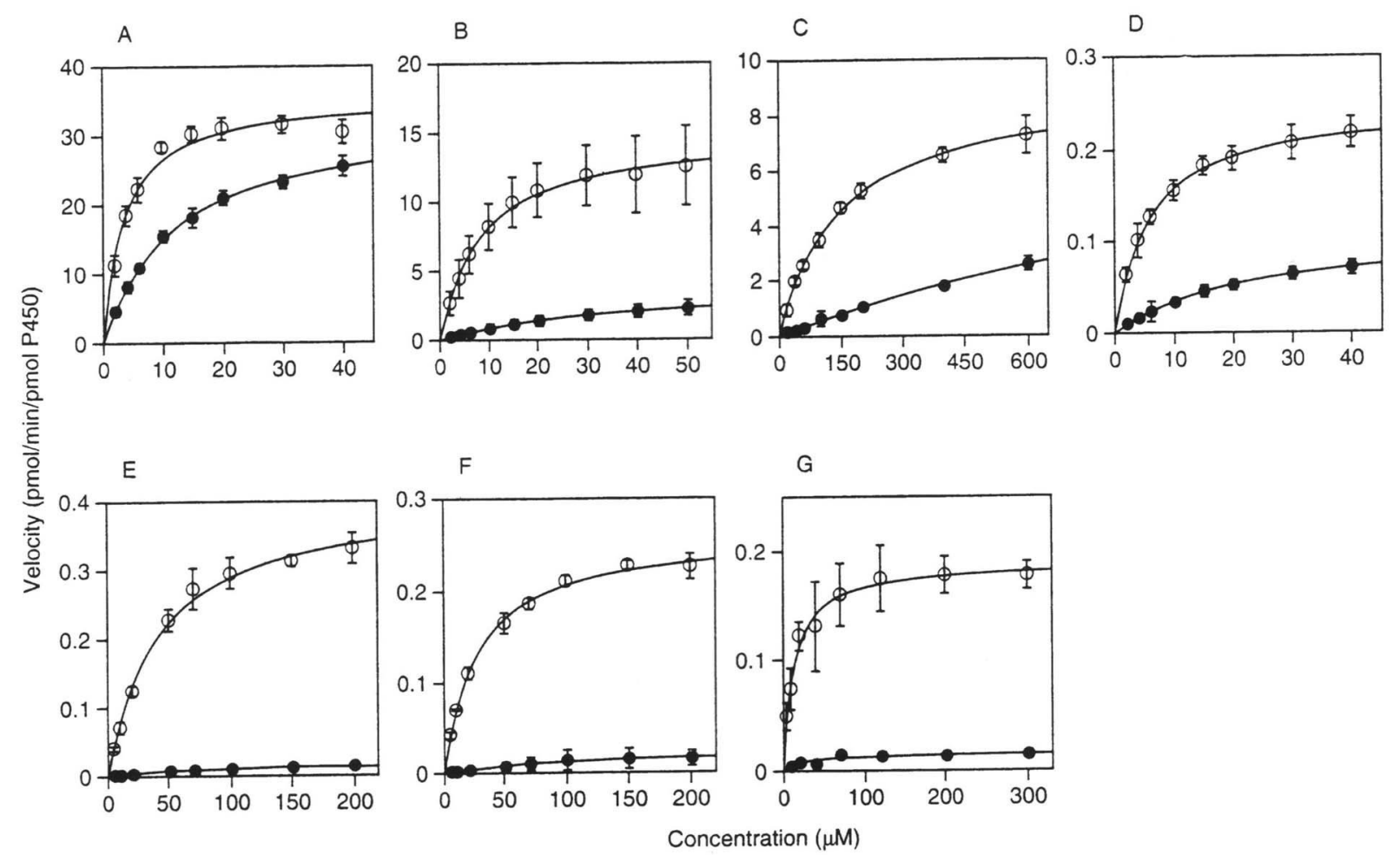
A: diclofenac 4'-hydroxylation
B: Mefenamic acid 3'-methylhydroxylation
C: Tolbutamide methylhydroxylation
D: S-Warfarin 7-hydroxylation
E: Piroxicam 5'-hydroxylation

F: Tenoxicam 5'-hydroxylation

G: Phenytoin 4-hydroxylation

Open circle: Wild-type CYP2C9

Closed circle: Leu359 variant

Fig. 4 Michaelis-Menten plots for various substrates of CYP2C9 by wild-type CYP2C9 and Leu ${ }^{359}$ variant $^{17)}$. 
CYP2C9*2 のヘテロ接合体と野生型のホモ接合体の患 者で比較したした結果では, ワーファリンの維持量が野 生型より $20 \%$ 低いとの報告もあり ${ }^{20)}$ ，活性が幾分低下 する可能性も残されている．CYP2C9*2 はコーカサス 人種で 8〜 $12 \%$ の頻度で認められるのに対し, 日本人を 含むモンゴル人種ではまだ確認されていないことから極 めて低い頻度でしか存在しないと考えられている。

CYP2C9*4 は日本人のてんかん患者から見出された 变異遺伝子であり, 369 番目のイソロイシンがトレオニ ンに変わる21)。頻度は低いと考えられているが, $C Y P 2 C 9^{*} 3$ と同じ部位のアミノ酸が置換していること から活性低下の可能性が示唆されている.

CYP2C9*5 はエキソン 7 の 1 塩基置換に伴って 360 番目のアスパラギン酸がグルタミン酸に変わる遺伝子変 異であり, 昆虫細胞発現系における活性は野生型の 8 13\%に低下する22).CYP2C9*5 は現在のところアフリ カ人でのみその存在が確認されており, 遺伝子頻度は約 3\%である.

\section{CYP3A4}

In vivo における CYP3A4 の活性には大きな個人差が 存在するが，それが遺伝子多型で説明されるか否かは 現在のところ不明である。しかし，CYPで代謝を受 ける薬物の半数以上が CYP3A4 によるものであること から，この分子種に臨床的に意味のある多型が存在す るか否かは重要な問題である. 現在までに C Y P $3 A 4$ 遺 伝子の翻訳領域に 12 , 非翻訳領域に 5 つの遺伝子変異 が報告されている1)。このうち $5^{\prime}$ 上流の変異である $C Y P 3 A 4^{*} 1 B$ についてはミダゾラムを用いた検討から in vivo でのクリアランスの低下が示唆されているが, 変異群と対照群で人種の偏りがあり, 結果をそのままに は受け取るには問題が残る23).

$C Y P 3 A 4^{*} 2$ は 222 番目のセリンがプロリンに置換さ れる变異で, 発現系を用いた検討からニフェジピンの水 酸化活性が野生型の 12～15\%に低下することが明らか にされている24). しかし，テストステロン $6 \beta$-水酸化活 性に大きな変化は認められず, in vivo で実際に活性が 低下するか否かは現在のところ不明である。この変異は 日本人ではほとんど認められない。

$C Y P 3 A 4^{*} 3$ は 445 番目のメチオニンがスレオニンに 置換する変異で中国人の被験者から見出された．この変 異の頻度と CYP3A4 活性に及ぼす影響についてはまだ 明らかにされていない24). 中国人ではその他 3 つの変 異遺伝子 $\left(C Y P 3 A 4^{*} 4,{ }^{*} 5,{ }^{*} 6\right)$ の存在が報告されてい る25). 前二者は尿中のコーチゾールと $6 \beta$-水酸化コーチ ゾールの比から, $C Y P 3 A 4^{*} 6$ についてはフレームシフ トを伴うことから活性の低下が示唆されている.

最近, 213 人のコーカサス人種の DNA 試料を用い
て CYP3A4 遺伝子のコード領域に存在する SNP の 解析が行われ，8つのアミ/酸置換を伴う変異遺伝子が 確認された ${ }^{26)}$. これらの遺伝子を大腸菌に発現させ活 性を野生型と比較した結果, 活性がほぼ検出されなく なったものが $2 つ\left(C Y P 3 A 4^{*} 8,{ }^{*} 13\right)$, 発現量の有意な 低下を示したものが $1 つ\left(C Y P 3 A 4^{*} 11\right)$, 代謝物の生成 パターンおよび酵素学的な特徵が変化したものが 1 つ (CYP3A4*12) 見出された. しかし, いずれの遺伝子発 現頻度も $1 \%$ 以下であり, CYP3A4 の個人差にはそれ程 大きな要因になっていないと推測されている.これらの 変異遺伝子の他人種における頻度は明らかにされていな い. 上記以外に, 論文としてはまだ発表されていない CYP3A4 の変異遺伝子が 6 つ存在する1).

\section{5. その他の CYP}

CYP1A2 については非翻訳領域に $7 つ$, 翻訳領域に 5 つの変異遺伝子が報告されており, このうち $C Y P 1 A 2^{*} 1 C$ では誘導の低下, $C Y P 1 A 2^{*} 1 F$ では増強 が示唆されている11.

CYP2E1 については非翻訳領域に $3 つ$, 翻訳領域に 6 つの変異遺伝子が報告されているが, in vivoにおける 活性に大きな影響を与える変異はまだ報告されていな (1).

CYP2A6についてはこれまでに 9 つの変異遺伝子と 遺伝子増幅が報告されている. 日本人では $C Y P 2 A 6$ 遺 伝子の全欠損 $\left(C Y P 2 A 6^{*} 4\right)$ が比較的高い頻度で存在 し, 日本人に打潰伝子頻度が約 $20 \%$ に達する 1 .

CYP2B6 については最近グリシンからヒスチジンへ の置換を伴う変異の存在が明らかにされた．この変異の 日本人における頻度は約 $20 \%$ あ゙あ

\section{おわりに}

CYP は薬物の代謝にかかわる最も主要な酵素群であ り, CYP の遺伝子多型は薬物の効果や副作用発現に大 きな影響を与える可能性がある. 現在, 世界中で薬物代 謝酵素を含めた有用な SNP の探索が行われており, 我 国でもファルマスニップコンソーシアムが 180 個の薬 物動態関連遺伝子について日本人における SNP の探索 と頻度解析を行っている. おそらくここ数年の間に主要 な CYP の遺伝子情報の蓄積が急速に進み, 医薬品開発 や臨床における適正使用に利用できる基盤が整ってくる ものと思われる.

\section{文献}

1) Home Page of the Human Cytochrome P450 (CYP) Allele, http://www.imm.ki.se/CYPPalleles/

2) Eichelbaum M, Gross AS: The genetic polymorphism of debrisoquine/sparteine metabolism-clinical aspects. 
Pharmacol Ther 46: 377-94, (1990).

3) Griese EU, Zanger UM, Brudermanns U, Gaedigk A, Mikus G, Morike K, Stuven T, Eichelbaum M: Assessment of the predictive power of genotypes for the in-vivo catalytic function of CYP2D6 in a German population. Pharmacogenetics 8: 15-26, (1998).

4) Yokoi T, Kosaka Y, Chida M, Chiba K, Nakamura H, Ishizaki T, Kinoshita M, Sato K, Gonzalez FJ, kamataki T: A new CYP2D6 allele with nine base insertion in exon 9 in a Japanese population associated with poor metabolizer phenotype. Pharmacogenetics 6: 395-401, (1996).

5) Chida M, Yokoi T, Kosaka Y, Chiba K, Nakamura H, Ishizaki T, Yokota J, Kinoshita M, Sato K, Inaba M, Aoki Y, Gonzalez FJ, Kamataki T.: Genetic polymorphism of CYP2D6 in Japanese population. Pharmacogenetics 9: 601605, (1999).

6) Kubota T, Yamaura Y, Ohkawa H, Hara H, Chiba K: Frequencies of CYP2D6 mutant alleles in a normal Japanese population and metabolic activity of dextromethorphan $\mathrm{O}_{-}$ demethylation in different CYP2D6 genotypes. $\mathrm{Br} \mathrm{J} \mathrm{Clin}$ Pharmacol 50: 31-34, (2000).

7) Nishida Y, Fukuda T, Yamamoto I, Azuma J: CYP2D6 genotypes in a Japanese population: Low frequencies of CYP2D6 gene duplication but high frequency of $C Y P 2 D 6^{*}$ 10. Pharmacogenetics 10: 567-70, (2000)

8) Johansson I, Oscarson M, Yue QY, Bertilsson L, Sjoqvist $\mathrm{F}$, Ingelman-Sundberg M: Genetic analysis of the Chinese cytochrome P4502D locus: Characterization of variant CYP2D6 genes present in subjects with diminished capacity for debrisoquine hydroxylation. Mol Pharmacol 46: 4529, (1994).

9) Dalen P, Dahl ML, Ruiz ML, Nordin J, Bertilsson L: 10Hydroxylation of nortriptyline in white persons with $0,1,2$, 3, and 13 functional CYP2D6 genes. Clin Pharmacol Ther. 63: 444-52, (1998).

10) Ishizaki T, Horai Y. Cytochrome P450 and the metabolism of proton pump inhibitors-emphasis on rabeprazole. Aliment Pharmacol Ther 13 (Suppl 3): 27-36, (1999).

11) Bertilsson L: Geographical/interracial differences in polymorphic drug oxidation. Current state of knowledge of cytochromes P450 (CYP) 2D6 and 2C19. Clin Pharmacokinet 9: 192-209, (1995).

12) Furuta $T$, Ohashi $K$, Kamata $T$, Takashima M, Kosuge $K$, Kawasaki T, Hanai H, Kubota T, Ishizaki T, Kaneko E: Effect of genetic differences in omeprazole metabolism on cure rates for Helicobacter pylori infection and peptic ulcer. Ann Intern Med 129: 1027-30, (1998).

13) Goldstein JA, de Morais SM: Biochemistry and molecular biology of the human CYP2C subfamily. Pharmacogenetics 4: 285-99, (1994).

14) Kubota T, Chiba K, Ishizaki T: Genotyping of Smephenytoin 4'-hydroxylation in an extended Japanese population. Clin Pharmacol Ther 60: 661-666, (1996).

15) Miners JO, Birkett DJ: Cytochrome P4502C9: An enzyme of major importance in human drug metabolism. Br J Clin Pharmacol 45: 525-38 (1998).

16) Takanashi K, Tainaka H, Kobayashi K, Yasumori T,
Hosokawa M, Chiba K: CYP2C9Ile359 and Leu359 variants: Enzyme kinetics study seven substrates. Pharmacogenetics 10: 95-104 (2000).

17) Shimamoto J, Ieiri I, Urae A, Kimura M, Kubota T, Chiba $\mathrm{K}$, Ishizaki T, Otsubo K, Higuti S: Lack of differences in diclofenac (a substrate for CYP2C9) pharmacokinetics in healthy Japanese volunteers with respect to the single CYP2C9*3 allele. Eur J Clin Pharmacol 56: 65-68 (2000).

18) Nasu K, Kubota T, Ishizaki T: Genetic analysis of CYP2C9 polymorphism in a Japanese population. Pharmacogenetics 7: 405-9 (1997).

19) Yamazaki $H$, Inoue $K$, Chiba $K$, Ozawa $N$, Kawai T, Suzuki Y, Goldstein JA, Guengerich FP, Shimada T: Comparative studies on the catalytic roles of cytochrome P450 2C9 and its Cys- and Leu-variants in the oxidation of warfarin, flurbiprofen, and diclofenac by human liver microsomes. Biochem Pharmacol 56: 243-51 (1998).

20) Furuya H, Fernandez-Salguero P, Gregory W, Taber H, Steward A, Gonzalez FJ, Idle JR: Genetic polymorphism of CYP2C9 and its effect on warfarin maintenance dose requirement in patients undergoing anticoagulation therapy. Pharmacogenetics 5: 389-92 (1995).

21) Imai J, Ieiri I, Mamiya K, Miyahara S, Furuumi H, Nanba E, Yamane M, Fukumaki Y, Ninomiya H, Tashiro N, Otsubo K, Higuchi S: Polymorphism of the cytochrome P450 (CYP) 2C9 gene in Japanese epileptic patients: Genetic analysis of the CYP2C9 locus. Pharmacogenetics 10: 85-9, 2000

22) Dickmann LJ, Rettie AE, Kneller MB, Kim RB, Wood AJ, Stein CM, Wilkinson GR, Schwarz UI: Identification and functional characterization of a new CYP2C9 variant (CYP2C $\left.9^{*} 5\right)$ expressed among African Americans. Mol Pharmacol 60: 382-7 (2001).

23) Wandel C, Witte JS, Hall JM, Stein CM, Wood AJ, Wilkinson GR: CYP3A activity in African American and European American men: Population differences and functional effect of the CYP $3 A 4^{*} 1 B 5^{\prime}$-promoter region polymorphism. Clin Pharmacol Ther 68: 82-91 (2000).

24) Sata F, Sapone A, Elizondo G, Stocker P, Miller VP, Zheng W, Raunio H, Crespi CL, Gonzalez FJ: CYP3A4 allelic variants with amino acid substitutions in exons 7 and 12 : Evidence for an allelic variant with altered catalytic activity. Clin Pharmacol Ther 67: 48-56 (2000).

25) Hsieh KP, Lin YY, Cheng CL, Lai ML, Lin MS, Siest JP, Huang JD: Novel mutations of CYP3A4 in Chinese. Drug Metab Dispos 29: 268-73 (2001).

26) Eiselt R, Domanski TL, Zibat A, Mueller R, PresecanSiedel E, Hustert E, Zanger UM, Brockmoller J, Klenk HP, Meyer UA, Khan KK, He YA, Halpert JR, Wojnowski L: Identification and functional characterization of eight CYP3A4 protein variants. Pharmacogenetics 11: 447-58 (2001).

27) Ariyoshi N, Miyazaki M, Toide K, Sawamura Yi, Kamataki T: A single nucleotide polymorphism of CYP2b6 found in Japanese enhances catalytic activity by autoactivation. Biochem Biophys Res Commun 281: 1256-60 (2001). 